\title{
Primary cerebral rhabdomyosarcoma and the problem of medullomyoblastoma
}

\author{
P. W. LEEDHAM
}

\author{
From the Department of Morbid Anatomy, The London Hospital, London
}

SUMMARY A case of primary rhabdomyosarcoma in the right cerebral hemisphere of a 45 year old woman is reported. This was treated by surgical excision but death occurred 10 months after the first symptom. The histogenesis of such a tumour is discussed. The clinical and pathological features of 15 previously reported similar tumours of the CNS are compared. Most of these occurred in the cerebellum in children where they have been regarded as medullomyoblastomas (a variant of medulloblastoma), teratomas, or rhabdomyosarcomas. Few have been recorded in adults and only one previously in the cerebrum. All of these tumours tend to have a short clinical course, although survival time seems to be significantly improved by surgical excision followed by radiotherapy. The remarkable morphological similarities between the tumours are discussed. Argyrophilic fibrils were demonstrated in the present case and in an unrelated rhabdomyosarcoma of the jaw. This observation may invalidate the main criterion used for separating medullomyoblastomas and teratomas from rhabdomyosarcomas in this group of tumours. It is concluded that at present all these tumours should be regarded as rhabdomyosarcomas.

Tumours of the central nervous system (CNS) containing striated muscle elements are rare, especially when teratomas are excluded. A case of primary rhabdomyosarcoma of the cerebrum is reported here. A comparison with other similar tumours which have occurred in the CNS leads to a reappraisal of the concept of medullomyoblastoma.

\section{CASE REPORT}

In July 1969, E.P., a 45 year old housewife (LH No. 504560) developed transitory involuntary jerking movements of the left foot. Three weeks later similar attacks occurred on successive days lasting 5 to 10 minutes on each occasion. The left shoulder was also affected and examination after the attacks showed moderate residual weakness of the left arm and leg. She became drowsy and developed a dense left hemiplegia with some loss of joint position sense on the left, bilateral ptosis, and impairment of conjugate deviation of the eyes to the left. An electroencephalogram indicated a space occupying lesion in the right cerebral hemisphere, and a carotid angiogram showed an avascular lesion in the right parietal zone with $1.5 \mathrm{~cm}$ shift of the midline vessels to the left and evidence of early tentorial herniation.
At craniotomy a small intracerebral haematoma was discovered in the right posterior frontal region, and this was evacuated. Biopsy of the wall of the cavity showed only gliosis. Her level of consciousness, but not the hemiplegia, improved at first, but over the next two weeks deteriorated to the previous level. Re-exploration showed a cerebral abscess at the site of the previous haematoma but this was sterile on culture. After this there was a further temporary improvement but a few days later she was again deeply unconscious and had a left homonymous hemianopia. At the beginning of September the craniotomy was reopened and the cavity decompressed but there were no new findings and her condition did not improve. Three weeks later a multilocular abscess in the right cerebral hemisphere was excised in toto. Histological examination showed areas of undifferentiated malignant tumour of uncertain origin in the wall of the abscess. Over the next five months there was a gradual improvement in her condition and she was able to walk with the aid of a tripod. The left arm remained weak and the visual field defect was unchanged. During March 1970 she became drowsy and complained of headache. There was a precipitous deterioration in her level of consciousness, with raised intracranial pressure and bilateral pyramidal signs. One hundred and fifty 
millilitres of opalescent fluid were aspirated from the craniotomy site but she became deeply unconscious and remained so until she died towards the end of April 1970, 10 months after the onset of her illness.

\section{PATHOLOGY}

SURGICAL MATERIAL (SD/6558/69) The material received after total excision of the abscess consisted bone. The brain $(1,107 \mathrm{~g})$ was soft with flattening of the cerebral convolutions on the left and bilateral uncal grooving. Mottled haemorrhagic tumour was $z_{0}$ visible through a $5.0 \mathrm{~cm}$ diameter defect in the right $\stackrel{\subseteq}{5}$ parietal cortex and in this region the left hemisphere on bulged across the midline. The brain was fixed in $4 \%$ formol-saline for three weeks and then sliced. The 0 slices showed a large tumour, up to $5.5 \mathrm{~cm}$ in

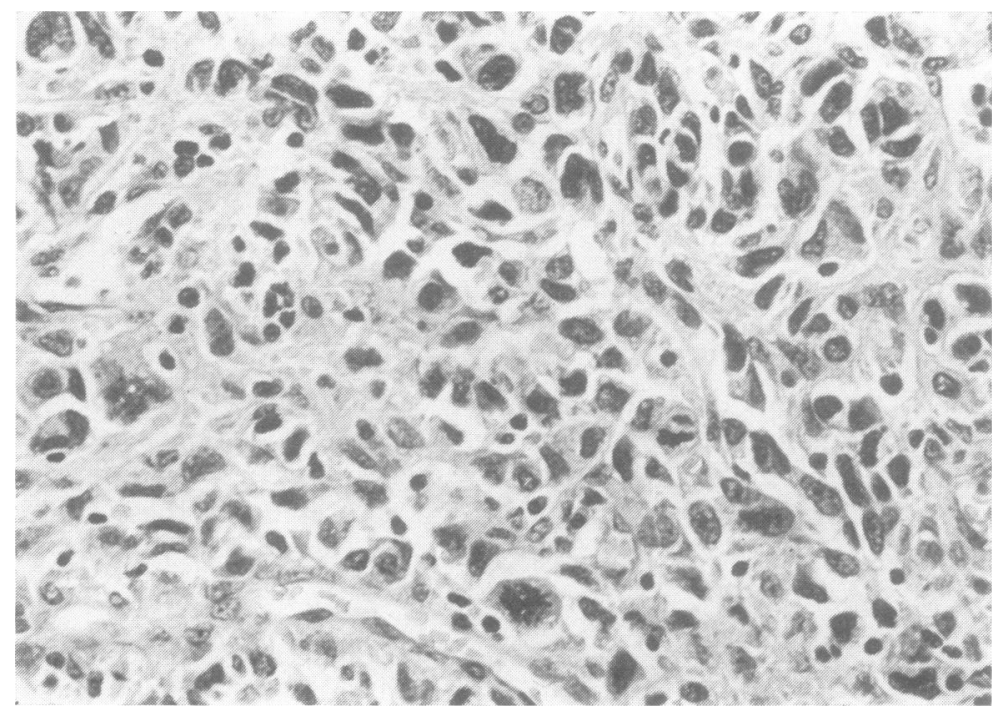

FIG. 1. Surgical material showing a pleomorphic cellular $\vec{\circ}$ tumour with occasional mitoses. Capillary blood vessels are seen within the tumour. Haematoxylin and eosin, $\times 350$.

of a ragged roughly spherical mass of soft brain tissue $7.0 \mathrm{~cm}$ in diameter, weighing $176 \mathrm{~g}$. It contained multilocular abscess cavities up to $4.5 \mathrm{~cm}$ in diameter. Parts of the wall were thick and fibrous but other areas adjoined brain tissue without fibrous demarcation. Microscopy showed large areas of necrosis and granulation tissue with surrounding gliosis but areas of undifferentiated pleomorphic tumour of uncertain origin were also present (Fig. 1). Review of these sections after the necropsy material was available revealed some strap-like cells with cross-striations within the areas of granulation tissue.

NECROPSY (No. 85/70) Necropsy was performed 40 hours after death. The body weighed $30.4 \mathrm{~kg}$ and was $162 \mathrm{~cm}$ long. There was a large surgical scar in the scalp of the right frontoparietal region deep to which there was an oval defect in the calvarium, $9.5 \times 8.5 \mathrm{~cm}$. The right cerebral cortex was adherent to the scalp in this area and was dissected free with difficulty. A plastic reservoir drained the left lateral ventricle through a small trephine in the left parietal maximum diameter, which occupied and distorted the middle third of the right cerebral hemisphere (Fig. 2). It extended from the level of the optic chiasm to the posterior parietal region where it occupied the body of the lateral ventricle. Superolaterally it bulged through the cortical defect where it was partly covered by fresh blood clot, and partly by gliotic capsule. The cut surface showed some firm $\overline{\bar{o}}$ white areas and other multilocular cystic areas which contained green/grey gelatinous material (Fig. 2). There was considerable disorganization of the ventricular system by the tumour on the right side and some dilatation on the left. Both frontal lobes were oedematous. The brain-stem, cerebellum, spinal cord, and cerebral vessels were normal.

There was a well-developed bilateral broncho- 8 pneumonia in the lower lobes of both lungs. The remaining organs were normal and there was no evidence of tumour elsewhere.

MICROSCOPY The gelatinous and cystic areas of the tumour (Fig. 2) were composed of amorphous $\odot$ eosinophilic and necrotic material with some areas $N$ 


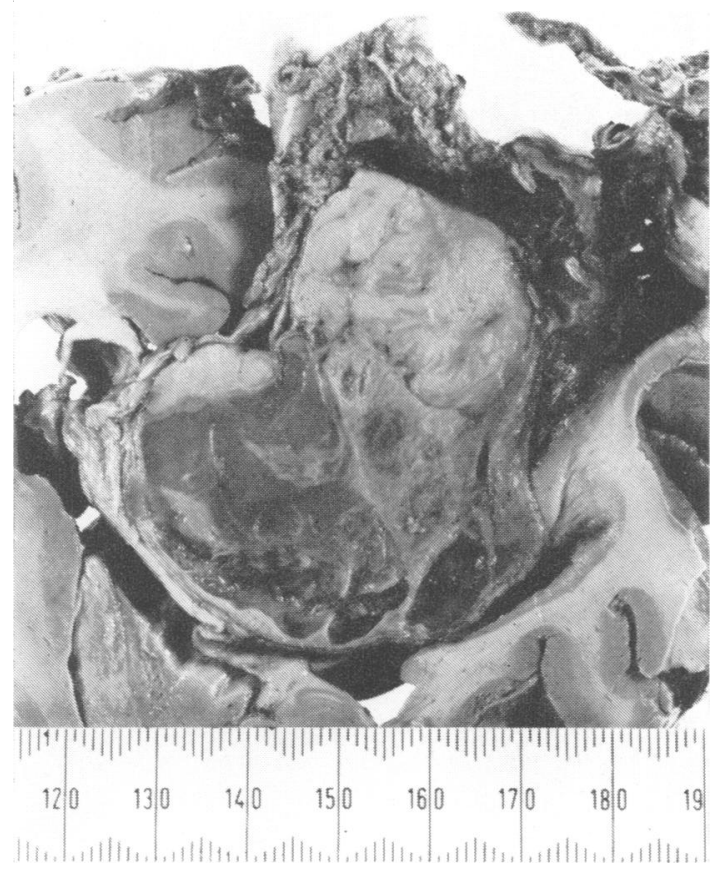

FIG. 2. Right cerebral tumour at necropsy. It distorts the ventricular system below and is partly covered by gliotic capsule and blood clot above where it penetrates the cortical surface. The cut surface shows pale solid areas and darker cystic areas.

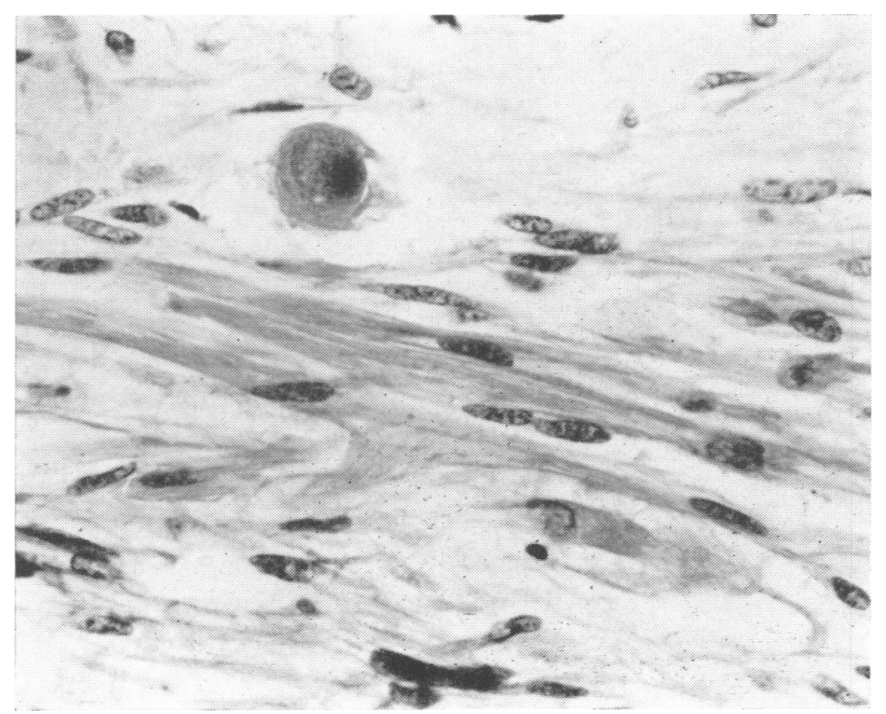

FIG. 3. Necropsy material showing strap-like spindle cells of varying size and a large ovoid-cell with abundant granular cytoplasm. $H$ and $E, \times 350$. 


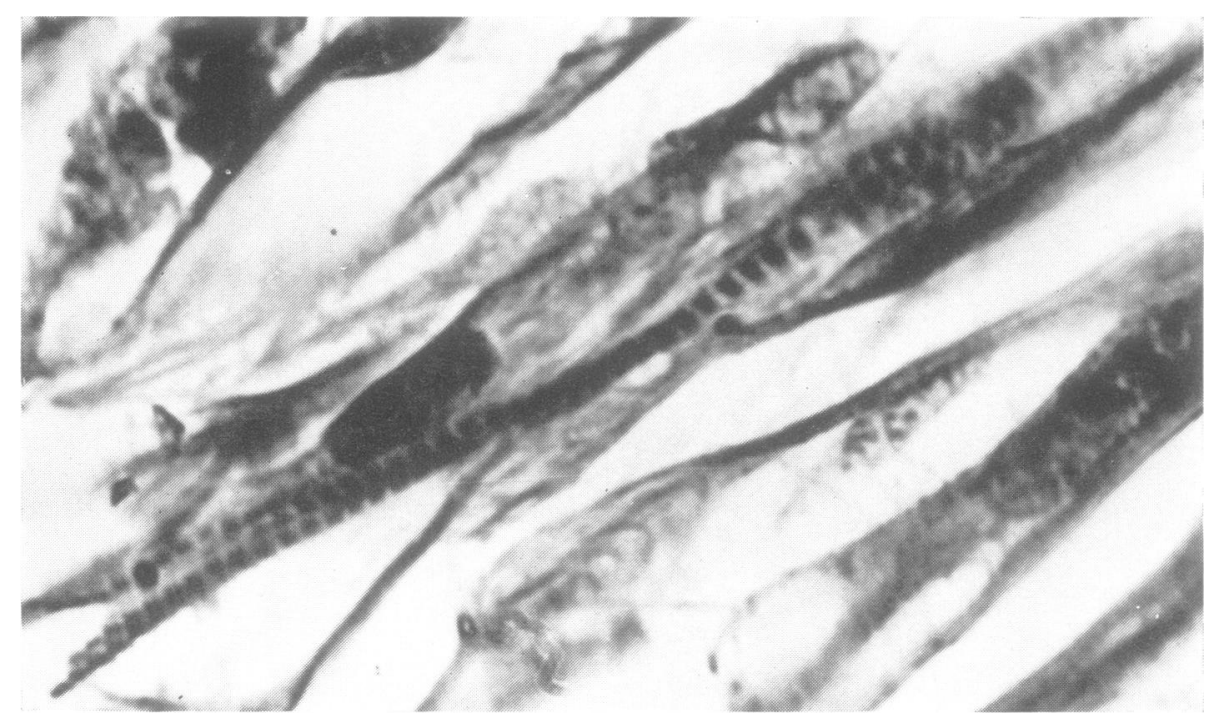

FIG. 4. Cross-striations in a strap-cell at necropsy. Phosphotungstic acid haematoxylin, $\times 1400$.

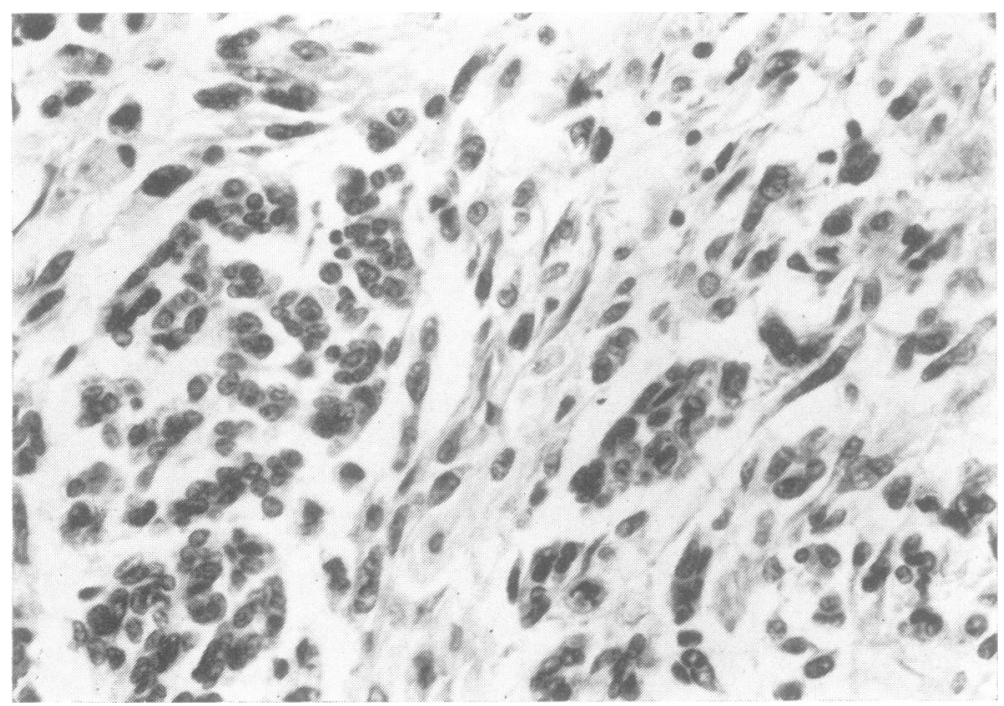

FIG. 5. Small cell areas which resemble those seen in the surgical material. Transitional spindle cell forms are present. $H$ and $E, \times 350$ 
of granulation tissue. A malignant tumour of variable histological pattern was present in the firm white areas (Fig. 2) and in other areas bordering on adjacent brain tissue. In some places it had widely dispersed stellate cells with few mitoses within a loose connective tissue stroma; the appearances resembled embryonic mesenchyme. In other areas there were interlacing bundles of spindle cells, many of which were strap-like with granular eosinophilic cytoplasm (Fig. 3). Some giant, oval, or round cells with similar abundant cytoplasm were also present
(Fig. 3). Cross-striations were occasionally seen in the strap forms on haematoxylin and eosin sections and were numerous in sections stained with phosphotungstic acid haematoxylin (Fig. 4). Areas of undifferentiated cells which resembled those seen in the surgical material were present particularly at the growing edge (Fig. 5). They contained clusters of small cells with a moderate number of mitoses mixed with larger cells which showed occasional giant and multinucleate forms. Early transitions to spindle cell forms were clearly seen (Fig. 5) and thin-
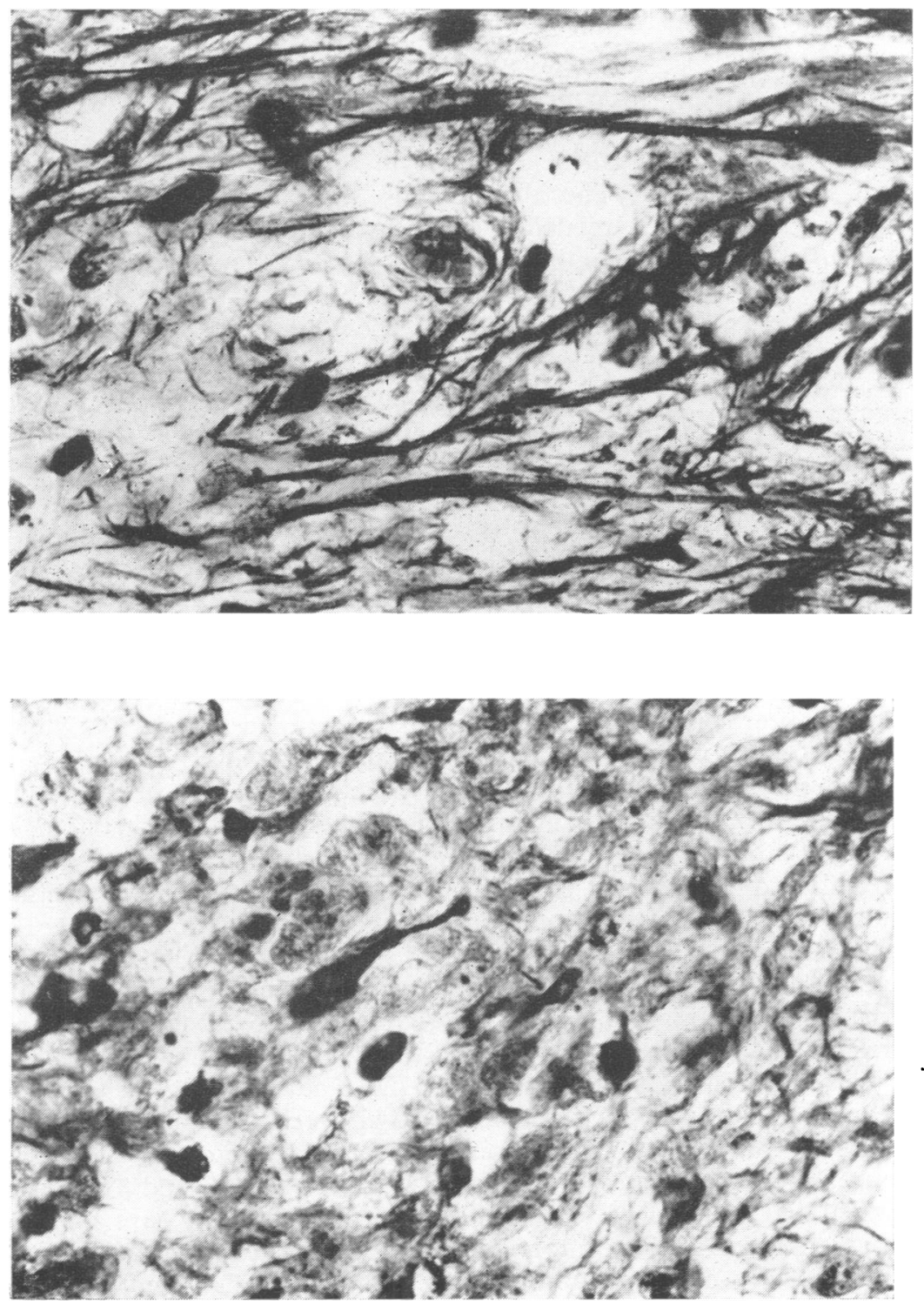

FIG. 6. Frozen section of necropsy material from the present case. Argyrophilic fibrils radiate from cells of all kinds. Weil-Davenport, $\times 560$.

FIG. 7. Frozen section of necropsy material from an unrelated rhabdomyosarcoma of the jaw. There are occasional short argyrophilic fibrils arising from tumour cells. Weil-Davenport, $\times 560$. 
walled vascular channels were present in the loose connective tissue background. Nervous tissue was not present within the tumour substance and no other ectodermal or endodermal derivatives were seen.

Frozen sections of formalin fixed tumour tissue, taken to include all the areas mentioned, were stained by the silver techniques of Weil-Davenport, Bielschowsky, and Scharenberg. Control sections were performed on normal brain tissue. By each method numerous argyrophilic fibrils of varying size were demonstrated radiating from cells of all kinds (Fig. 6). In view of this apparently nonspecific argyrophilia, tissue from an undifferentiated embryonal rhabdomyosarcoma of the jaw in a 22 year old man was stained in a similar fashion. Again a few argyrophilic fibrils were seen despite the anaplastic nature of the tumour (Fig. 7). Electron microscopy was attempted on the tumour tissue but the electronmicrographs were of poor quality due to the inappropriate fixation in formol-saline. However, fragmented and disorganized myofibrils composed of filaments with the appearance of actin and myosin were seen in the cytoplasm of both the straplike cells and the small undifferentiated cells.

Sections from the lung confirmed the presence of moderate bilateral bronchopneumonia. No significant abnormality was seen in the other tissues of the body and there was no evidence of tumour deposits elsewhere.

\section{DISCUSSION}

The necropsy confirmed the presence of a primary tumour of the right cerebral hemisphere with no tumour deposits elsewhere. In view of the light and electron microscope appearances a diagnosis of rhabdomyosarcoma seemed most likely and the absence of derivatives from other embryonic germ layers helped confirm this. In the biopsy material the diagnosis was obscured by a severe inflammatory reaction and predominance of the undifferentiated component of the tumour. The symptoms and signs corresponded with the site of the tumour at necropsy but the clinical course was unusual. The initial event was probably haemorrhage within the tumour from thin-walled vascular channels, and an abscess formed after the blood clot was evacuated.

Rhabdomyosarcomas are rare tumours outside of the central nervous system and fall into two distinct but related groups (Evans, 1966; Stout and Lattes, 1967). In adults they occur mainly in the soft tissues of the trunk and extremities; they are often pleomorphic with little evidence of cross-striated cells, although more differentiated forms have been recorded of (Evans, 1966). In children and adolescents the head and neck and urogenital tract are the main sites of origin. In these tumours more differentiation may occur and cells with cross-striations are more frequently seen. The fact that many rhabdomyosarcomas arise in tissues that do not normally contain striated muscle has led some $\stackrel{\overrightarrow{\vec{S}}}{\overrightarrow{\mathrm{s}}}$ authorities to believe that these tumours derive $\overline{0}$ directly from unstable mesenchyme which undergoes neoplastic change (Evans, 1966; Willis, 1967). A similar origin from mesenchyme $\triangle$ would also adequately explain the presence of $\%$ such a tumour in the central nervous system. $\vec{\circ}$ The alternative is that the present tumour is related to the mixed mesenchymal and neuro- $\vec{G}$ epithelial tumours which have recently been described (Goldman, 1969; Shuangshoti and Netsky, 1971). These tumours differ from the of present case in that they contain a combined glioma and sarcoma in which varying degrees of differentiation into fibroblastic, chondroblastio $\vec{\circ}$ and rhabdomyoblastic elements have occurre® They are probably related to gliosarcone (Rubinstein, 1956). An overgrowth of a rhabd\& 80 myoblastic element in such a tumour coula o mimic a rhabdomyosarcoma. However, deriv $\overrightarrow{0}$ tion from unstable mesenchyme would seem more likely explanation.

Only one previous case of a cerebral rhabdomyosarcoma has been found (Koide, 1957) and this is poorly documented. There are, however,

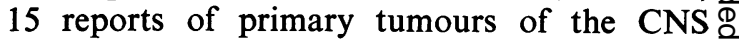
which might also be regarded as rhabdomyo- $\overrightarrow{\vec{F}}$ sarcomas. The clinical and pathological details 3 of these are summarized in the Table together with the present case.

The first 11 listed are similar to each other (Table). They are all cerebellar tumours which? have occurred in children aged 2 to 11 years and $\frac{5}{3}$ all are known to have been in the midline. The sex ratio is $4 \mathrm{~F}: 7 \mathrm{M}$. The clinical histories are of $\mathrm{O}$ variable length (two weeks to nine months). In many cases death occurred before or soon after surgery but in three cases $(3,4$, and 8$)$ surgical $\frac{7}{0}$ excision followed by radiotherapy gave a significant improvement in survival time (12 to $23 \%$ months). Distant metastases have not occurred $N$ 
TABLE

DETAILS OF POSSIBLE RHABDOMYOSARCOMAS OF CNS

\begin{tabular}{|c|c|c|c|c|c|c|c|c|c|c|}
\hline No. & Source & Sex & $\begin{array}{l}\text { Age } \\
(y r)\end{array}$ & $\begin{array}{l}\text { Diag- } \\
\text { nosis }\end{array}$ & Site & $\begin{array}{l}\text { Microscopic } \\
\text { features }\end{array}$ & $\begin{array}{l}\text { Other } \\
\text { necropsy } \\
\text { findings }\end{array}$ & $\begin{array}{l}\text { Length } \\
\text { of } \\
\text { histury } \\
\text { (months) }\end{array}$ & Treatment & $\begin{array}{c}\text { Survival } \\
\text { time } \\
\text { (months) }\end{array}$ \\
\hline 1 & $\begin{array}{l}\text { Marinesco and } \\
\text { Goldstein (1933) }\end{array}$ & $\mathbf{F}$ & 5 & $\mathbf{M M}$ & Vermis & $\begin{array}{l}\text { Small cell areas; cross- } \\
\text { striated cells near } \\
\text { vessels }\end{array}$ & $\begin{array}{r}\text { No tumour } \\
\text { elsewhere }\end{array}$ & 3 & None & 3 \\
\hline 2 & $\begin{array}{l}\text { Russell and } \\
\text { Rubinstein (1971) } \\
\text { (case from 1934) }\end{array}$ & $\mathbf{M}$ & $2 \frac{1}{2}$ & $\mathbf{M M}$ & Vermis & $\begin{array}{l}\text { Small cell areas; cross- } \\
\text { striated spindle cells }\end{array}$ & $\begin{array}{l}\text { Brain only } \\
\text { examined }\end{array}$ & 一 & Decompression & $4 / 28$ \\
\hline 3 & Zülch (1942) & $\mathbf{M}$ & 5 & $\mathbf{M M}$ & Vermis & $\begin{array}{l}\text { Medulloblast-like } \\
\text { cells; smooth } \\
\text { muscle-like cells near } \\
\text { vessels }\end{array}$ & No necropsy & 3 & $\begin{array}{l}\text { Excision. } \\
\text { DXT }\end{array}$ & 12 \\
\hline 4 & $\begin{array}{l}\text { Ingraham and } \\
\text { Bailey (1946) } \\
\text { (case 4) }\end{array}$ & $\mathbf{M}$ & $10 \frac{1}{2}$ & $\mathbf{T}$ & $\begin{array}{l}\text { Midline } \\
\text { cerebellum }\end{array}$ & $\begin{array}{l}\text { Small cells with neuro- } \\
\text { fibrils; large cells } \\
\text { with cross-striations }\end{array}$ & No necropsy & $\longrightarrow$ & $\begin{array}{l}\text { Excision. } \\
\text { DXT }\end{array}$ & 12 \\
\hline 5 & $\begin{array}{l}\text { Bofin and Ebels } \\
\text { (1963) }\end{array}$ & $\mathbf{M}$ & 6 & MM & $\begin{array}{l}\text { Vermis and } \\
\text { right cere- } \\
\text { bellum }\end{array}$ & $\begin{array}{l}\text { Cellular areas resem- } \\
\text { bling medulloblasts; } \\
\text { cross-striated spindle } \\
\text { cells }\end{array}$ & $\begin{array}{l}\text { No tumour } \\
\text { elsewhere }\end{array}$ & 8 & Partial excision & v. short \\
\hline 6 & Boellaard (1964) & $\mathbf{M}$ & 8 & $\mathbf{M M}$ & Vermis & $\begin{array}{l}\text { Cellular areas resem- } \\
\text { bling neuroblasts; } \\
\text { cross-striated spindle } \\
\text { cells }\end{array}$ & $\begin{array}{l}\text { Lepto- } \\
\text { meninges } \\
\text { infiltrated. } \\
\text { Brain only } \\
\text { examined }\end{array}$ & Short & None & v. short \\
\hline 7 & $\begin{array}{l}\text { Gullotta (1967) } \\
\text { (case 11) }\end{array}$ & $\mathbf{F}$ & $3 \frac{1}{2}$ & MM & Vermis & $\begin{array}{l}\text { Small cell areas; cross- } \\
\text { striated spindle cells }\end{array}$ & $\begin{array}{r}\text { No general } \\
\text { necropsy }\end{array}$ & 9 & Exploration & v. short \\
\hline 8 & $\begin{array}{l}\text { Legier and Wells } \\
\text { (1967) }\end{array}$ & $\mathbf{M}$ & $3 \frac{1}{2}$ & RS & Vermis & $\begin{array}{l}\text { Stellate mesenchyme; } \\
\text { spindle cells with } \\
\text { cross-striations. No } \\
\text { neuroblastic forms }\end{array}$ & $\begin{array}{l}\text { Extensive } \\
\text { lepto- } \\
\text { meningeal } \\
\text { spread in } \\
\text { cord }\end{array}$ & Short & $\begin{array}{l}\text { Excision. } \\
\text { DXT }\end{array}$ & 23 \\
\hline 9 & $\begin{array}{l}\text { Shuangshoti et al. } \\
\text { (1968) }\end{array}$ & $\mathbf{F}$ & 4 & RS & Vermis & $\begin{array}{l}\text { Small cells, pleo- } \\
\text { morphic cells, } \\
\text { spindle cells with } \\
\text { cross-striations. No } \\
\text { neuroblastic forms }\end{array}$ & $\begin{array}{l}\text { Lepto- } \\
\text { meninges } \\
\text { of brain } \\
\text { base in- } \\
\text { filtrated }\end{array}$ & $2 / 52$ & None & $13 / 28$ \\
\hline 10 & $\begin{array}{l}\text { Unpublished case of } \\
\text { R. S. Beckett } \\
\text { quoted in } 9\end{array}$ & $\mathbf{F}$ & 9 & RS & $\begin{array}{l}\text { Midline } \\
\text { cerebellum }\end{array}$ & Similar to case 9 & 一 & - & - & - \\
\hline 11 & $\begin{array}{l}\text { Misugi and Liss } \\
\quad(1970)\end{array}$ & $\mathbf{M}$ & $7 \frac{1}{2}$ & $\mathbf{T}$ & $\begin{array}{l}\text { Midline } \\
\text { cerebellum }\end{array}$ & $\begin{array}{l}\text { Small cell arcas with } \\
\text { neuroblastic forms; } \\
\text { cross-striated spindle } \\
\text { cells }\end{array}$ & No necropsy & Short & Decompression & $3 / 28$ \\
\hline 12 & $\begin{array}{l}\text { O'Connell (1946) } \\
\text { (case 1) }\end{array}$ & $\mathbf{F}$ & 5 & $\mathbf{T}$ & Lumbar cord & $\begin{array}{l}\text { Spindle cells with cross- } \\
\text { striations }\end{array}$ & $\begin{array}{l}\text { Spread in } \\
\text { spinal cord } \\
\text { associated } \\
\text { with spina } \\
\text { bifida }\end{array}$ & 6 & Exploration & 1 \\
\hline 13 & $\begin{array}{l}\text { Lopes de Faria } \\
\text { (1957) }\end{array}$ & $\mathbf{F}$ & 52 & RS & $\begin{array}{l}\text { Left cerebellar } \\
\text { hemisphere }\end{array}$ & $\begin{array}{l}\text { Stellate mesenchyme; } \\
\text { spindle cells with } \\
\text { cross-striations. No } \\
\text { neuroblastic forms }\end{array}$ & $\begin{array}{l}\text { No tumour } \\
\text { elsewhere }\end{array}$ & 5 & None & v. short \\
\hline 14 & Koide (1957) & $\mathbf{M}$ & 15 & $\mathbf{R S}$ & $\begin{array}{l}\text { Right cerebral } \\
\text { hemisphere }\end{array}$ & $\begin{array}{l}\text { Pleomorphic cells; } \\
\text { small cells, cross- } \\
\text { striated spindle cells. } \\
\text { No neuroblastic } \\
\text { forms }\end{array}$ & $\begin{array}{l}\text { No tumour } \\
\text { elsewhere }\end{array}$ & 4 & $\begin{array}{l}\text { Decompression } \\
\text { DXT }\end{array}$ & 2 \\
\hline 15 & $\begin{array}{l}\text { Galatioto and } \\
\text { Gaddoni (1971) } \\
\text { (case 1) }\end{array}$ & $\mathbf{F}$ & 26 & MY & $\begin{array}{l}\text { Left cerebellar } \\
\text { hemisphere }\end{array}$ & $\begin{array}{l}\text { Small cell areas; } \\
\text { spindle-cell areas. } \\
\text { No striations seen }\end{array}$ & $\begin{array}{r}\text { No general } \\
\text { necropsy }\end{array}$ & Short & Exploration & v. short \\
\hline 16 & Present case & $\mathbf{F}$ & 45 & $\mathbf{R S}$ & $\begin{array}{l}\text { Right cerebral } \\
\text { hemisphere }\end{array}$ & $\begin{array}{l}\text { Cellular pleomorphic } \\
\text { areas; bundles of } \\
\text { cells with cross- } \\
\text { striations; stellate } \\
\text { mesenchyme }\end{array}$ & $\begin{array}{l}\text { No tumour } \\
\text { elsewhere }\end{array}$ & $6 / 52$ & Excision & 10 \\
\hline
\end{tabular}

$\mathbf{M M}=$ medullomyoblastoma $; \mathbf{T}=$ teratoma $\mathbf{R S}=$ rhabdomyosarcoma $; \mathbf{M Y}=$ myosarcoma. $\mathbf{D X T}=$ radiotherapy . 
but cases 6,8 , and 9 showed infiltration of the leptomeninges. The microscopic appearances of individual tumours are strikingly similar with descriptions of cellular small cell areas, and less cellular spindle cell areas mentioned in many reports. Spindle cells with cross-striations are described in every case except that of Zülch (1941) who did not demonstrate stripes and regarded these as smooth muscle cells (case 3). However, his case resembles the others in all other respects and must be included in this group of tumours. Misugi and Liss (1970) claimed to have demonstrated axon-like structures in the electronmicrographs of their tumour (case 11) but their illustrations are not convincing and they also described glial fibres which may indicate an admixture of normal neural tissue within their tumour.

Six of the tumours in this group (cases 1, 2, $3,5,6$, and 7) were called medullomyoblastomas mainly because neurofibrils were demonstrated within the small cell areas. Other authors (cases 4 and 11) felt that this finding indicated a teratomatous origin. These tumours with apparent neuroblastomatous elements have usually been regarded as variants of medulloblastoma, but recently Russell and Rubinstein (1971) have preferred to call them malignant teratoid tumours. Neural elements were not demonstrated in the remainder (cases 8, 9, and 10). Even so these pure rhabdomyosarcomas have been related to medullomyoblastomas by most authors, although it has been suggested that they represent rhabdomyoblastic differentiation in an embryonal sarcoma (Russell and Rubinstein, 1971). However, because of the many similarities described above it would seem that the first 11 cases listed (Table) belong to the same group of tumours.

The tumour described by O'Connell (1946) occurred in the lumbar cord in a 5 year old girl and was associated with spina bifida (case 12). This was probably a rhabdomyosarcoma arising in a hamartoma associated with the congenital defect. The remaining tumours (cases 13, 14, 15, and 16 , present case) occurred in the cerebrum or cerebellum of adults and had a rapid clinical course. The microscopic appearances are very similar. Galatioto and Gaddoni (1971) failed to demonstrate cross-striations (case 15), but examination of illustrations and paraffin sections of their case shows close similarities in all other $z$ respects. Clearly it would seem reasonable to classify these tumours together and examine on their relationship to the childhood group.

Although the adult and childhood tumours occur in different sites, they do not vary in behaviour or morphology. In both groups the clinical course is short and stormy and a com-. parison of the histological appearances reveals $\overrightarrow{\vec{B}}$ remarkable similarities. Cellular areas composed of small round or oval cells with some pleomorphism are described in both groups as are less cellular areas of spindle cells. Foci of primitive mesenchyme and cells with cross-striations are also a common feature. It has been possible to examine sections from the childhood tumour described by Russell and Rubinstein (1971) at $\vec{\omega}$ this hospital (case 2) and the cellular areas of $\stackrel{S}{S}$ that tumour are indistinguishable from similar cellular areas in the present case. In addition $\dot{\omega}$ there are cells present which are transitional or between the spindle and round cell elements of in the present case. On morphological ground $\overrightarrow{8}$ therefore, there is a strong case for includin both childhood and adult tumours in the same group.

The demonstration of neurofibrils by silve क impregnation techniques has been used $\overrightarrow{0}$ distinguish a neuroectodermal element in those tumours of the childhood groups called medullomyoblastoma or teratoma. Argyrophilic processes have been demonstrated in the present case and also in material from a primary rhabdomyosarcoma of the jaw. The reaction in this $\frac{Q}{\mathscr{Q}}$ type of tumour may therefore be non-specific, a $\overrightarrow{\vec{P}}$ finding which invalidates the main criterion for $\stackrel{3}{3}$ distinguishing a neuroblastomatous element.

It is concluded, therefore, that on present evidence it would be best to regard all these tumours as rhabdomyosarcomas.

I wish to thank Mr. T. King for allowing me to study one of his cases and I am grateful to Professor $H$. Urich for his encouragement, and criticism of the $\frac{9}{9}$ manuscript. Mr. H. Oliver, Miss S. Robinson, and $D$ Mr. R. Hammond are thanked for technical, secretarial, and photographic assistance. The work $N$ was in part supported by the Cancer Research Campaign. 


\section{REFERENCES}

Boellaard, J. W. (1964). Ein Medulloblastom mit quergestreiften Muskelfasern. Archiv für Psychiatrie und Nervenkrankheiten, vereinigt mit Zeitschrift für die gesamte Neurologie und Psychiatrie, 206, 228-236.

Bofin, P. J., and Ebels, E. (1963). A case of medullomyoblastoma. Acta Neuropathologica, 2, 309-311.

Evans, R. W. (1966). Histological Appearances of Tumours. 2nd edition, p. 48-57. Livingstone: Edinburgh.

Goldman, R. L. (1969). Gliomyosarcoma of the cerebrum. American Journal of Clinical Pathology, 52, 741-744.

Galatioto, S., and Gaddoni, G. (1971). Miosarcomi primitivi del SNC. Acta Neurologica (Bari), 26, 297-302.

Gullotta, F. (1967). Das sogenannte Medulloblastoma. Springer: Berlin.

Ingraham, F. D., and Bailey, O. T. (1946). Cystic teratomas and teratoid tumors of the central nervous system in infancy and childhood. Journal of Neurosurgery, 3, 511532.

Koide, O. (1957). A case of primary rhabdomyosarcoma of the brain [Japanese]. Gann, 48, 645-647.

Legier, J. F., and Wells, H. A., Jr. (1967). Primary cerebellar rhabdomyosarcoma. Case report. Journal of Neurosurgery, 26, 436-438.

Lopes de Faria, J. (1957). Rhabdomyosarcoma of cerebellum. Archives of Pathology, 63, 234-238.

Marinesco, G., and Goldstein, M. (1933). Sur une forme anatomique, non encore décrite, de médulloblastome; médullo-myoblastome. Annales d'Anatomie Pathologique, 10, 513-525.
Misugi, K., and Liss, L. (1970). Medulloblastoma with cross-striated muscle. A fine structural study. Cancer (Philad.), 25, 1279-1285.

O'Connell, J. E. A. (1946). The subarachnoid dissemination of spinal tumours. Journal of Neurology, Neurosurgery, and Psychiatry, 9, 55-62.

Rubinstein, L. J. (1956). The development of contiguous sarcomatous and gliomatous tissue in intracranial tumours. Journal of Pathology and Bacteriology, 71, 441-459.

Russell, D. S., and Rubinstein, L. J. (1971). Pathology of Tumours of the Nervous System, 3rd ed., p. 15. Arnold: London.

Shuangshoti, S., and Netsky, M. G. (1971). Neoplasms of mixed mesenchymal and neuroepithelial origin. Journal of Neuropathology and Experimental Neurology, 30, 290-309.

Shuangshoti, S., Piyaratn, P., and Viriyapanich, P. L. (1968). Primary rhabdomyosarcoma of cerebellum-necropsy report. Cancer (Philad.), 22, 367-371.

Stout, A. P., and Lattes, R. (1967). Tumors of the soft tissues. In Atlas of Tumor Pathology, 2nd Series, Fascicle 1, p. 134144. Armed Forces Institute of Pathology: Washington, D.C.

Willis, R. A. (1967). Pathology of Tumours. 4th edn., p. 757771. Butterworths, London.

Zülch, K. J. (1941). Ein Medulloblastom mit glatten Muskelfasern. Archiv für Psychiatrie und Nervenkrankheiten, vereinigt mit Zeitschrift für die gesamte Neurologie und Psychiatrie, 114, 349-352. 